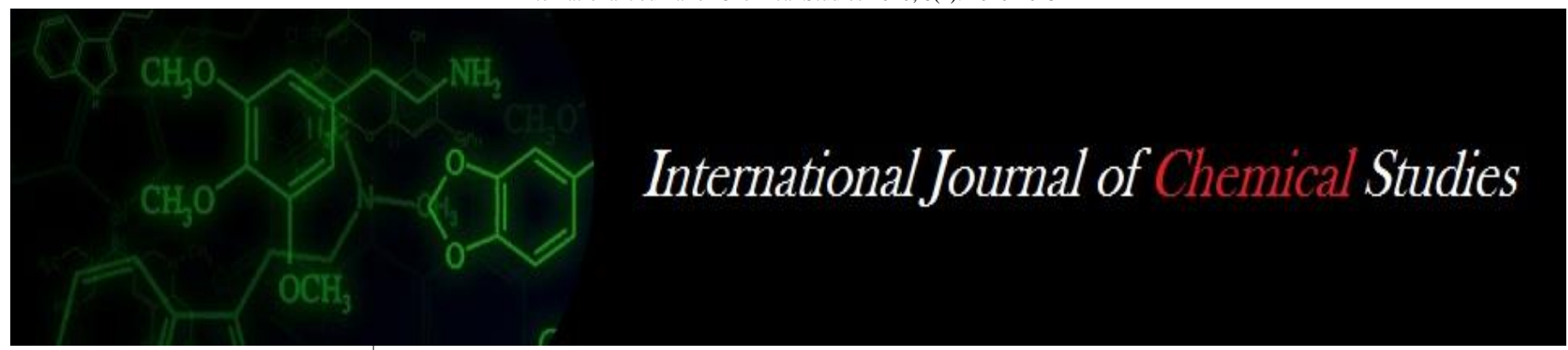

P-ISSN: 2349-8528

E-ISSN: 2321-4902

www.chemijournal.com

IJCS 2020; 8(4): 1040-1045

(C) 2020 IJCS

Received: 28-05-2020

Accepted: 30-06-2020

B Thirupam Reddy

PhD. Scholar, Department of

Agricultural Entomology,

College of Agriculture, Dharwad,

Karnataka, India

RS Giraddi

Professor, Department of

Agricultural Entomology,

College of Agriculture, Dharwad,

Karnataka, India

DN Kambrekar

Assistant Professor, Department of Agricultural Entomology,

College of Agriculture, Dharwad, Karnataka, India
Corresponding Author:

B Thirupam Reddy

PhD. Scholar, Department of

Agricultural Entomology,

College of Agriculture, Dharwad,

Karnataka, India

\section{Assessment of phenological and biochemical basis of resistance induced by organic, conventional and conservation practices in groundnut (Arachis hypogaea L.) to Spodoptera litura}

\author{
B Thirupam Reddy, RS Giraddi and DN Kambrekar
}

DOI: https://doi.org/10.22271/chemi.2020.v8.i4h.9739

\begin{abstract}
The studies on biophysical factors at 60 DAS of groundnut revealed lower leaf succulency $(72.37 \%)$ and higher leaf thickness $\left(6.52 \mathrm{mg} / \mathrm{cm}^{2}\right)$ imparted induced resistance against pest infestation in plants receiving organic nourishment compared to conventional and conservation practices. The biochemical constituent, phenol recorded higher amount $(0.53 \mathrm{mg} / \mathrm{g}$ fr.wt- 1 at $60 \mathrm{DAS})$ in plants nourished with organics resulting into lower pest incidence owing to induced resistance. The lower amounts of sugars, free amino acids, soluble proteins and prolines also imparted resistance to the plants receiving organics whereas higher quantities recorded in conventional treatments resulted in susceptibility to pests. Morphological characters like plant height, leaf area index, etc. were enhanced in organically nourished plants.
\end{abstract}

Keywords: Groundnut, Spodoptera litura, leaf thickness and phenol

\section{Introduction}

Nutrient management plays a vital role in the growth and yield of crops. Chemical fertilizers are the major source of nutrients, but its escalating cost coupled with increasing demand and adverse effect on soil health have made them a problematic resource so far. Indiscriminate use of pesticides for management of various pests and diseases also has lead to pesticide resistance, pest resurgence, secondary pest outbreaks, destruction of beneficial insects and other natural fauna, accumulation of undesirable residues resulting in environmental pollution and severe health hazards, This necessitated for adoption of eco-friendly farming with efficient use of organics and biologicals in crop production.

Groundnut is an important oilseed crop in the World and is an important source of digestible proteins, cooking oil and also vitamins (Savage and Keenan, 1994) ${ }^{[26]}$. Insect pests are important constraints in achieving higher groundnut yields. In India, the annual yield losses by insect pests in groundnut are about 15 per cent which accounts for about 1.6 million tonnes and 25.27 billion rupees (Dhaliwal et al., 2010) ${ }^{[8]}$. Among the insects, polyphagous pest $S$. litura (Lepidoptera: Noctuidae) is an important pest of groundnut besides affecting tobacco, cotton, pulses and several vegetables crops (Singh and Jalali, 1997) ${ }^{[29]}$. It has been reported that an infestation level of one larva per plant during the seedling or flowering stage resulted in $20 \%$ yield loss (Dhir et al., 1992) ${ }^{[9]}$. Severe outbreak of the pest results in 30-40\% loss in pod formation (Joshi 2005). In India, transitional tract of Karnataka (Dharwad) has been identified as hot spot for $S$. litura during kharif season, where yield loss to an extent of 66.6 per cent was reported in groundnut (Kulkarni, 1989) ${ }^{[16]}$. Larvae feed gregariously on leaves and fresh growth causing extensive damage (Patil, 2000) ${ }^{[20]}$. Though many effective insecticide molecules are suggested to combat Spodoptera, they are not eco-friendly and add to the cost of cultivation especially in semi-arid tropics where farmers Grow groundnut as subsistence crop. This paper is mainly focus on impact of organic nutrients induced resistance in groundnut to $S$. litura. Organic practices enhance and maintain soil organic carbon status for obtaining sustainable crop yields. The increasing complexities of insect pest management and current discernment of problems associated with chemical control of insect pests, have led to an 
increased emphasis on organic agriculture that keeps out the use of chemical fertilizers and pesticides from the perspective of eco-friendly management which has many advantages over conventional agriculture. Insect resistance in crop plants is attributed to various biophysical and biochemical factors (Painter, 1951; Norris and Kogan, 1980; David and Easwaramoorthy, 1988, Peter et al., 1995; Jinsa et al., 2012; Abhilash, 2018) ${ }^{[19,18,7,21,12,1]}$. The plant resistance to insect pests is a complex phenomenon, which results from a series of interactions between insects and plants. It is controlled by several morphological features like leaf succulence, leaf thickness, leaf area and biochemical constituents like, sugars, phenols, tannins, proteins, amino acids and several secondary plant metabolites, which impair normal feeding, oviposition, development and survivability of insects. Therefore, studies were made on the influence of organic and inorganic nutrients on these characters in imparting resistance to insect attack.

\section{Material and Methods \\ Collection of Experimental Data on Biophysical Parameters}

Five plants were selected randomly from each plot for recording observations on various biophysical parameters at 60 DAS in groundnut crop in different farming systems.

\section{Leaf Succulence}

Leaf succulence was expressed as relative water content (RWC). A composite sample of leaf discs was taken and the fresh weight was determined, followed by flotation on water for up to $4 \mathrm{hrs}$. The turgid weight was then recorded and the leaf tissue is subsequently oven-dried to a constant weight at about $85^{\circ} \mathrm{C}$ and dry weight was taken as described by Barrs and Weatherley (1962). RWC was calculated by using the formula;

$$
\text { RWC }=\frac{\text { Fresh weight }- \text { dry weight }}{\text { Turgid weight }- \text { dry weight }} \times 100
$$

\section{Leaf area}

Leaf area was measured by disc method as suggested by Vivekanandan et al. (1972). Leaf lets were separated from petiole and fifty discs of known size were prepared through a cork borer from randomly selected fifty leaves from five plants. The discs and the remaining parts of the 50 leaves as well as the remaining leaves were oven dried at 75 to $80^{\circ} \mathrm{C}$ to a constant weight and leaf area was calculated by using the formula as given below.

$$
\mathrm{LA}=\frac{\mathrm{WaxA}}{\mathrm{Wd}}
$$

LA- Leaf area of five plants in $\mathrm{cm}^{2}$

Wa- Oven dry weight of all the leaves (inclusive of 50 discs) in $g$

Wd-Oven dry weight of 50 discs in $g$

A-Area of 50 discs in $\mathrm{cm}^{2}$

\section{Leaf thickness}

Leaf thickness was expressed in specific leaf weight (SLW).

$$
\mathrm{SLW}\left(\mathrm{mg} / \mathrm{cm}^{2}\right)=\frac{\text { Leaf weight per plant }(\mathrm{mg})}{\text { Leaf area per plant }\left(\mathrm{cm}^{2}\right)}
$$

\section{Plant Height}

Plant height was measured from ground level to the tip of the main shoot of the five tagged plants and was recorded. The mean of the five plants was recorded as plant height in $\mathrm{cm}$.

\section{Biochemical studies}

The various biochemical parameters like sugars, free amino acids, soluble proteins, proline and phenol content were estimated at different growth stages at 60 DAS of groundnut crop.

\section{Sampling}

The sampling was done at 60 days after sowing. Hundred grams of leaves from middle portion of the plants were randomly collected and were used for biochemical analysis.

\section{Extraction of Plant Tissues in Alcohol}

The estimation of metabolites requires their complete extraction from tissues. The activities of the enzymes, which synthesize and utilize them, need to be stopped at once to get reliable values. The plant constituents possess different solvents. Though water is the universal solvent, it does not penetrate tissues quickly enough to stop enzymatic activity. In this context alcohol especially hot alcohol, is the choicest solvent for extraction.

\section{Reagents}

Two grams of tissue was weighed and made into small pieces and plunged immediately in boiling alcohol. Then it was cooled and passed through double-layered muslin cloth. The pieces of the tissue were ground thoroughly using a mortar and pestle with little alcohol, and it was passed through muslin cloth. The above step was repeated once again. The filtrates were pooled and filtered through Whatmann No. 41 filter paper and made up to $25 \mathrm{ml}$ with alcohol. The extract was stored in a refrigerator at $4{ }^{\circ} \mathrm{C}$. This alcoholic extract was used further for analysis of reducing sugar, non-reducing sugar, total sugar and phenols.

\section{Clarification of Alcoholic Extracts}

Dark coloured alcohol extracts of the tissues create a great problem in analytical procedure. Heavy metal salts were used for clarification of alcoholic extracts.

\section{Reagent and Procedure}

Saturated solution of neutral lead acetate and saturated solution of disodium hydrogen phosphate were used. Two ml of saturated lead acetate solution was added drop wise to 10 $\mathrm{ml}$ of the coloured alcoholic extract and saturated solution of di-sodium hydrogen phosphate was added drop wise till the precipitation is completed. The above solutions were mixed thoroughly and kept overnight and filtered through Whatmann No. 1 filter papers and made up to $10 \mathrm{ml}$ with 80 per cent alcohol and stored in a refrigerator at $40{ }^{\circ} \mathrm{C}$.

\section{Estimation of Total Phenols}

Estimation of total phenols present in plant samples was determined following Folin-Ciocalteau Reagent (FCR) method (Bray and Thorpe, 1954) ${ }^{[5]}$.

\section{Reagents and Procedure}

Folin-Ciocalteau reagent (1\%) and Sodium carbonate (2\%) reagents were used. One $\mathrm{ml}$ of each alcohol extract was taken in a test tube to which one $\mathrm{ml}$ of folin-ciocalteau reagent followed by two $\mathrm{ml}$ of sodium carbonate solution (2\%) were 
added. The tubes were shaken well and heated in a hot water bath for exactly one minute and then cooled under running tap water. The blue coloured complex developed was diluted to $15 \mathrm{ml}$ with distilled water and its absorbance was read at 650 $\mathrm{nm}$ in a spectrophotometer. The amount of phenols present in sample was calculated from 3.6.3 Estimation of sugars. The estimation of total sugars and reducing sugars was done by following Nelson-Somogyi's method. The reducing sugar was estimated following Nelson's modification of Somogyi's method (Nelson, 1944) ${ }^{[17]}$.

\section{Reagents Used}

\section{Solution A}

Twenty five grams of anhydrous sodium carbonate, $25 \mathrm{~g}$ of sodium potassium tartrate, $20 \mathrm{~g}$ of sodium bicarbonate and 200 $\mathrm{g}$ of sodium sulphate were dissolved separately in distilled water and volume was made upto one litre.

\section{Solution B}

Fifteen gram of copper sulphate was dissolved in distilled water to which one or two drops of concentrated sulphuric acid were added and made up to $100 \mathrm{ml}$ volume with distilled water. Solutions A and B were mixed in 24:1 (v/v) proportion just before use.

\section{Arsenomolybdate reagent}

Twenty five gram of ammonium molybdate was dissolved in $450 \mathrm{ml}$ of distilled water. Twenty one $\mathrm{ml}$ of concentrated sulphuric acid was added and mixed with above solution. Three gram of sodium orthoarsenate was dissolved in $25 \mathrm{ml}$ distilled water. Both the solutions were mixed with stirring and placed in an incubator at $37{ }^{\circ} \mathrm{C}$ for $24-48 \mathrm{hrs}$. The reagent was stored in an amber coloured bottle.

\section{Procedure}

One ml of each sample (alcohol extract) was pipetted out into test tubes. To each one $\mathrm{ml}$ of extract, one ml of mixture of solution A and B was added and test tubes were heated on a hot water bath for $20 \mathrm{~min}$. After cooling under running tap water, one $\mathrm{ml}$ of arsenomolybdate reagent was added with immediate mixing. The volume of the above solution was made upto $15 \mathrm{ml}$, to dilute the density of the blue coloured complex. The absorbance of the solution was read at $510 \mathrm{~nm}$ in a spectrophotometer. The amount of reducing sugars was determined by using standard curve prepared with different concentrations of standard glucose.

Acid-hydrolysis of non-reducing sugar and its estimation as reducing sugar Non-reducing sugar was first hydrolyzed with the help of diluted mineral acid like hydrochloric acid. Then the hydrolyzate was neutralized and the reducing sugar was estimated by Nelson-Somogyi's method.

\section{Reagents Used}

1. 0.1 and $1 \mathrm{~N}$ hydrochloric acid and $1 \mathrm{~N}$ sodium hydroxide.

2. Phenolphthalein indicator solution in alcohol.

\section{Procedure}

One $\mathrm{ml}$ of each alcohol extract was taken in test tubes and to it $1.0 \mathrm{ml}$ of $1 \mathrm{~N}$ hydrochloric acid was added and the test tubes were then kept in a hot water bath at $50{ }^{\circ} \mathrm{C}$ for $20 \mathrm{~min}$. After cooling one drop of indicator was added and mixed well. To the solution $1 \mathrm{~N}$ sodium hydroxide was added drop wise till the colour turned to pink due to excess alkali. The excess alkali was neutralized with $0.1 \mathrm{~N}$ hydrochloric acid till the solution became colourless. Then, the volume was made upto $5.0 \mathrm{ml}$. From the above $5.0 \mathrm{ml}$ solution one $\mathrm{ml}$ was taken and reducing sugar present in the hydrolyzate was estimated by Nelson-Somogyi's method. The reducing sugar in the hydrolyzate was a measure of total sugar, the quantity of reducing sugar was subtracted from this value and it was multiplied by a conversion factor of 0.95 .

\section{Estimation of Free Amino Acid}

The estimation of total free amino acids was done following Ninhydrin method (Moore and Stein, 1984).

\section{Reagents Used}

1. Ninhydrin reagent: Stannous chloride $(0.8 \mathrm{~g})$ was dissolved in $500 \mathrm{ml}$ of $0.2 \mathrm{M}$ citrate buffer (pH 5.0) and to this $20 \mathrm{~g}$ of ninhydrin in $500 \mathrm{ml}$ of methyl cellosolve (2-methoxyethanol) was added.

2. Diluent Solvent: Equal volumes of water and $n$-propanol is mixed.

\section{Procedure}

Alcohol free extract of plant samples was pipetted out into separate test tubes together with the reagent blank and $1 \mathrm{ml}$ of ninhydrin reagent was added and the volume was made upto 2 $\mathrm{ml}$ by using distilled water. Test tubes were heated in a boiling water bath for 20 minutes. Five $\mathrm{ml}$ of diluent solution was added and mixed well and kept for $15 \mathrm{~min}$. Absorbance of purple colour was measured against reagent blank at 570 $\mathrm{nm}$ by using spectrophotometer. The amount of total free amino acids in samples were estimated using the standard curve prepared using different concentrations of standard leucine.

\section{Estimation of Proline}

Proline concentration was determined using the method of Bates et al. (1973) ${ }^{[4]}$.

\section{Reagents Used}

1. Acid ninhydrin: $1.25 \mathrm{~g}$ ninhydrin was warmed in $30 \mathrm{ml}$ glacial acetic acid and $20 \mathrm{ml} 6 \mathrm{M}$ phosphoric acid with agitation until dissolved and stored at $4^{\circ} \mathrm{C}$ and used within 24 $\mathrm{hr}$.
2. 3\% Aqueous Sulpho Salicylic Acid
3. Glacial Acetic Acid
4. Toluene
5. Proline

\section{Procedure}

Fresh leaves $(0.5 \mathrm{~g})$ were homogenized in $10 \mathrm{ml}$ of $3 \%$ aqueous sulpho salicylic acid. The homogenate was filtered through Whatman No. 2 filter paper. Two $\mathrm{ml}$ of the filtrate was mixed with an equal volume of acetic acid and acid ninhydrin and incubated for $1 \mathrm{~h}$ at $100{ }^{\circ} \mathrm{C}$. The reaction was terminated by placing the tube in an ice bath and extracted with $4 \mathrm{ml}$ of toluene. The extract was vortexed for 20 seconds and the toluene layer was separated and warmed to room temperature. The intensity of red colour developed was measured by using a spectrophotometer at $520 \mathrm{~nm}$. The amount of proline in the test sample was measured from the standard curve prepared using pure proline and proline content was expressed on fresh weight-basis using the formulae:

$\mathrm{mg}$ proline per $\mathrm{ml} \mathrm{x} \mathrm{ml}$ toluene $5 \mu$ moles per $\mathrm{g}$ tissue $=115.5$ $\mathrm{x}$ g sample 
Where, 115.5 is the molecular weight of proline.

\section{Estimation of Soluble Proteins}

Soluble proteins were estimated following Lowry's method (Lowry et al., 1951).

\section{Reagents Used}

1. Alkaline copper reagent:

Solution A ( $2 \%$ sodium carbonate in $0.1 \mathrm{~N} \mathrm{NaOH})$, Solution B ( $1 \%$ sodium potassium tartarate), Solution C (0.5\% copper sulfate). Solutions A, B, C were mixed in 100: 1: 1 proportion just before use.

\section{Folin-Ciocalteau Reagent (FCR) $1 \mathrm{~N}$}

\section{Procedure}

One $\mathrm{ml}$ of each alcohol extract was taken in test tube and 5.0 $\mathrm{ml}$ of alkaline copper reagent was added to it and then it was mixed thoroughly and allowed to react for 10 minutes followed by addition of half a ml of $1 \mathrm{~N} \mathrm{FCR}$ and kept in dark for 30 minutes. The blue coloured complex developed was diluted to $15 \mathrm{ml}$ with distilled water and its absorbance was read at $660 \mathrm{~nm}$ in a spectrophotometer. The amount of soluble proteins present in sample was calculated from a standard curve prepared using different concentrations of standard protein solution prepared using Bovine serum albumin (BSA).

\section{Results and Discussion \\ Impact of biophysical factors on the activity of $S$. litura in groundnut as influenced by organic and inorganic sources of nutrients.}

\section{A) Leaf succulency}

The nourishment in organic farming system significantly influenced the leaf succulency in different treatments of groundnut crop. The treatments viz., organic sources of nutrition registered significantly less leaf succulency $(72.37 \%)$ as against the maximum leaf succulency $(76.89 \%)$ recorded in conventional treatment. Conservation treatment practices recorded moderate levels $(71.28$ to $74.59 \%)$ of leaf succulency. Rao (2002) ${ }^{[24]}$ opined that the nitrogen content of the leaves in organically manured treatments of soybean was comparatively lower than the straight fertilized treatments, resulting in lesser leaf succulency thus reducing the incidence of $S$. litura. The correlation coefficients obtained between leaf succulency and larval populations of $S$. litura (0.81) were significant and positive indicating its role in imparting resistance to the host. Increase in the plant nitrogen through application of straight fertilizers increased the level of leaf succulency and this might have facilitated the increased feeding of defoliators due to thinner cell walls or higher turgidity of the tissues. Elanchezhyan et al. (2009) [10] obtained significant positive relationship between total chlorophyll and moisture content with shoot damage caused by Leucinodes orbonalis in brinjal. Similar association was reported by the earlier workers (Jinsa, et al., 2012; Abhilash et al., 2018) ${ }^{[12,1]}$ who reported increased palatability of the food material with more moisture content in case of susceptible varieties.

\section{B) Leaf Thickness}

The treatments showed significant difference in leaf thickness, with maximum thickness in organic treatments that recorded $6.52 \mathrm{mg} / \mathrm{cm}^{2}$ in groundnut as against minimum of $5.86 \mathrm{mg} / \mathrm{cm}^{2}$ in conventional treatments, where as in conservation treatments it ranged from 6.13 to $6.41 \mathrm{mg} / \mathrm{cm}^{2}$. Jinsa et al. (2012) ${ }^{[12]}$ reported maximum leaf thickness in soybean grown under organic sources of nutrition compared to conventional, which can be attributed to higher accumulation of epicuticular wax content in plants nourished with organics.

The relationship between leaf thickness and larval population $(\mathrm{r}=-0.69)$ was negative and significant, expressing its role in imparting resistance against defoliator pests. Jinsa et al. (2012) ${ }^{[12]}$ also observed the lowest incidence of major pests in soybean plants, having maximum leaf sheath thickness, treated with organic sources of nutrients.

\section{C) Leaf area}

The results with regard to leaf area in groundnut under different treatments revealed that maximum leaf area $(767.95$ $\mathrm{cm}^{2}$ ) was recorded in conventional treatment as against treatment with organic sources of nutrients which recorded comparatively minimum leaf area $\left(696.33 \mathrm{~cm}^{2}\right)$ and in Conservations treatments leaf area was observed in between 726.46 to $751.75 \mathrm{~cm}^{2}$. The correlation studies exhibited positive and significant relationship between leaf area and larval population $(\mathrm{r}=0.77)$. The present results are in agreement with Amjad et al. (2003) ${ }^{[2]}$ who gave an account on positive correlation with leaf area and soybean looper infestation in soybean.

\section{D) Plant Height}

Significantly higher plant height was observed in organic system treatment $(18.47 \mathrm{~cm}$.) as against conventional $(16.21$ $\mathrm{cm}$.), where as plant height in conservation treatments was in between organic and conventional treatments. The relationship between plant height and larval population of $S$. litura were positive but, non-significant $(\mathrm{r}=0.38)$. Similar results were also reported by Ramachandra reddy et al. (1998) ${ }^{[22]}$, Sharma et al. (2002), Ramgopal et al. (2003) ${ }^{[23]}$ and Shwetha (2007) ${ }^{[28]}$.

Impact of biochemical factors on the activity of $S$. litura in groundnut as influenced by organic and inorganic sources of nutrients.

\section{1) Total Phenols}

In the present investigation, the crop nourished with organics showed higher leaf phenol content of $0.53 \mathrm{mg} / \mathrm{g}$, than the conventional $(0.41 \mathrm{mg} / \mathrm{g})$ (Table- 1$)$. This might be a contributing factor for low incidence of pests in crops that received organics. Conservation treatments also showed higher phenol content compared to inorganically treated plots. Total foliar nitrogen increased as much as four fold with fertilizers (Rauzi, 1978) and increase in plant nitrogen content through fertilizers was reported to reduce the level of phenols (Jones, 1976).

The correlation studies showed a significant negative relationship ( $\mathrm{r}=-0.737$ in groundnut) (Table -2) between phenol content and defoliator population. Phenols are known to play an important role in plant defence against insects. Jinsa et al. (2014) ${ }^{[13]}$ observed a negative correlation between total phenolic content and defoliators in soybean. 
Table 1: Biochemical and biophysical traits in groundnut as influenced by organic, conservation and conventional practices

\begin{tabular}{|c|c|c|c|c|c|c|c|c|c|c|}
\hline \multirow[b]{2}{*}{ Farming systems } & \multicolumn{6}{|c|}{ Biochemical parameters } & \multicolumn{4}{|c|}{ Biophysical parameters } \\
\hline & $\begin{array}{c}\text { Total sugar } \\
(\mathbf{m g} \mathbf{g} \text { fresh } \\
\left.\mathbf{w t}^{-1}\right)\end{array}$ & $\begin{array}{l}\text { Reducing sugar } \\
\left(\mathrm{mg} \mathrm{g}_{\text {fresh }} \mathrm{wt}^{-1}\right)\end{array}$ & \begin{tabular}{|c|} 
Phenols \\
(mg g \\
fresh wt $^{-}$ \\
1 )
\end{tabular} & $\begin{array}{c}\text { Proline } \\
(\square M / g \\
\left.\text { fresh wt } t^{-1}\right)\end{array}$ & $\begin{array}{c}\text { Soluble } \\
\text { protein }(\mathrm{mg} g \\
\left.\text { fresh } \mathrm{wt}^{-1}\right)\end{array}$ & $\begin{array}{c}\text { Amino acid } \\
(\mathbf{m g} g \text { fresh } \\
\left.\text { wt }^{-1}\right)\end{array}$ & $\begin{array}{c}\text { Leaf } \\
\text { succulency } \\
(\%)\end{array}$ & $\begin{array}{c}\text { Leaf } \\
\text { thickness } \\
\left(\mathrm{mg} / \mathrm{cm}^{2}\right)\end{array}$ & $\begin{array}{l}\text { Leaf } \\
\text { area } \\
\left(\mathrm{cm}^{2}\right)\end{array}$ & $\begin{array}{c}\text { Plant } \\
\text { height } \\
(\mathbf{c m})\end{array}$ \\
\hline Organic & $4.72^{\mathrm{a}}$ & $1.06^{\mathrm{a}}$ & $0.53^{\mathrm{d}}$ & $0.97^{\mathrm{a}}$ & $4.56^{\mathrm{e}}$ & $4.47^{\mathrm{b}}$ & $72.37^{\mathrm{a}}$ & $6.52^{\mathrm{b}}$ & $696.33^{\mathrm{c}}$ & $18.47^{\mathrm{a}}$ \\
\hline $\begin{array}{l}\text { Broad bed furrow } \\
\text { with residue } \\
\text { retaintion }\end{array}$ & $5.21^{\mathrm{b}}$ & $1.11^{\mathrm{a}}$ & $0.48^{\mathrm{bc}}$ & $0.98^{\mathrm{a}}$ & $3.16^{\mathrm{a}}$ & $4.83^{\mathrm{c}}$ & $71.28 \mathrm{a}$ & $6.13^{\mathrm{a}}$ & $751.75^{\mathrm{bc}}$ & $17.13^{\mathrm{a}}$ \\
\hline $\begin{array}{l}\text { Broad bed furrow } \\
\text { with residue } \\
\text { incorporation }\end{array}$ & $5.12^{\mathrm{b}}$ & $1.16^{\mathrm{ab}}$ & $0.42^{\mathrm{b}}$ & $0.98^{\mathrm{a}}$ & $3.89^{\mathrm{c}}$ & $4.21^{\mathrm{a}}$ & $74.59 \mathrm{a}$ & $6.27^{\mathrm{ab}}$ & $763.82^{\mathrm{bc}}$ & $17.56^{\mathrm{a}}$ \\
\hline $\begin{array}{c}\text { Flat bed with residue } \\
\text { retaintion }\end{array}$ & $5.24^{\mathrm{b}}$ & $1.17^{\mathrm{ab}}$ & $0.47^{\mathrm{b}}$ & $1.02^{\mathrm{ab}}$ & $3.46^{\mathrm{b}}$ & $4.67^{\mathrm{c}}$ & $72.16^{\mathrm{a}}$ & $6.18^{\mathrm{ab}}$ & $726.46^{\mathrm{ab}}$ & $17.26^{\mathrm{a}}$ \\
\hline $\begin{array}{c}\text { Flat bed with residue } \\
\text { incorporation }\end{array}$ & $5.16^{\mathrm{b}}$ & $1.06^{\mathrm{b}}$ & $0.51^{\mathrm{c}}$ & $1.09^{\mathrm{b}}$ & $3.87^{\mathrm{c}}$ & $4.22^{\mathrm{a}}$ & $71.84^{\mathrm{a}}$ & $6.41^{\mathrm{b}}$ & $740.71^{\mathrm{ab}}$ & $17.18^{\mathrm{a}}$ \\
\hline Conventional & $5.39^{\mathrm{c}}$ & $1.32^{\mathrm{c}}$ & $0.41^{\mathrm{a}}$ & $1.25^{\mathrm{c}}$ & $4.12^{\mathrm{d}}$ & $5.09^{\mathrm{d}}$ & $76.89^{\mathrm{b}}$ & $5.86^{\mathrm{a}}$ & $767.95^{\mathrm{c}}$ & $16.21^{\mathrm{a}}$ \\
\hline S.Em $( \pm)$ & 0.06 & 0.05 & 0.01 & 0.02 & 0.07 & 0.05 & 1.00 & 0.11 & 11.09 & 1.08 \\
\hline CD@1\% & 0.24 & 0.19 & 0.04 & 0.08 & 0.27 & 0.20 & 4.07 & 0.44 & 45.13 & 4.40 \\
\hline
\end{tabular}

Means in the columns followed by same letters are not significantly different $(\mathrm{p}=0.01)$ by DMRT

Table 2: Correlation of biochemical and biophysical traits with Spodoptera litura population in groundnut as influenced by organic, conservation and conventional practices

\begin{tabular}{|c|c|}
\hline $\begin{array}{c}\text { Biochemical and biophysical } \\
\text { factors }\end{array}$ & $\begin{array}{c}\text { Larval population (r value) } \\
\text { (60 DAS) }\end{array}$ \\
\hline Total sugar & $0.808^{*}$ \\
\hline Reducing sugar & 0.749 \\
\hline Non reducing & - \\
\hline Phenol & -0.737 \\
\hline Proline & 0.743 \\
\hline Soluble protein & 0.689 \\
\hline Amino acid & 0.775 \\
\hline Leaf area & 0.775 \\
\hline Thickness & -0.692 \\
\hline Leaf succulency & 0.819 \\
\hline Plant height & $0.386^{\mathrm{NS}}$ \\
\hline
\end{tabular}

* Significant at 5 per cent level;

+NS- Non significant;

\section{2) Sugars}

Among different biochemical constituents sugars (Reducing sugars and non-reducing sugars) contribute greatly to susceptibility of the host. The results revealed that the treatments with organic sources of nutrition possessed reduced quantities of total sugars at the critical stages of crop growth $(4.72 \mathrm{mg} / \mathrm{g})$ as against conventional treatment $(5.39$ $\mathrm{mg} / \mathrm{g}$ ). However, in case of conservation treatments, it varied from 5.12 to $5.24 \mathrm{mg}$ per $\mathrm{g}$. The correlation studies revealed positive and significant relationship between reducing sugars and larval population $(r=0.74)$. Similar relationship existed between total sugars and larval population $(r=0.80)$. The results are in conformation with Chhabra et al. (1990) ${ }^{[6]}$, Halder et al. (2006) [11] and Jinsa et al. (2014) ${ }^{[13]}$ who reported a positive significant correlation between total sugars, reducing sugars and non-reducing sugars and pod damage in gram and defoliators on soybean respectively.

\section{3) Free Amino Acids}

The results with regard to free amino acids in groundnut grown under different systems revealed that organic sources of nutrients showed considerable impact in decreasing the free amino acid content of plants to $4.47 \mathrm{mg}$ per $\mathrm{g}$. This in turn reduced pest infestation in groundnut whereas, in plants which received NPK as inorganic fertilizers (conventional) recorded high amounts of free amino acids $(5.09 \mathrm{mg} / \mathrm{g})$. However, conservation treatments which received nutrients both in inorganic and organic forms, recorded moderate levels, 4.21 to $4.83 \mathrm{mg}$ per $\mathrm{g}$, which are next to organic source of treatments.

The free amino acids had a significant positive relationship with that of larval population $(\mathrm{r}=0.77)$ indicating its contribution in inducing susceptibility against $S$. litura. The organic sources of nutrients showed considerable impact in decreasing the free amino acid content of plants and in turn reduced the incidence of defoliator pests of groundnut. This is in line with earlier findings that lower amount of free amino acids in cotton imparted resistance to leaf hopper attack (Singh and Agarwal, 1988) ${ }^{[30]}$.

\section{4) Proline}

The leaf samples of soybean and groundnut plants in conventional agriculture treatments which received maximum pest damage recorded maximum proline content of $31.25 \mu \mathrm{M}$ per g. This might be due to the rapid accumulation of proline in relation to stress condition caused by heavy insect infestation. Whereas, in plants nourished with organics, proline content was less $0.97 \mu \mathrm{M}$ per $\mathrm{g}$. The proline content in conservation treatment ranged from 0.98 to $1.09 \mu \mathrm{M}$ per $\mathrm{g}$. The correlation between proline content and pest infestation revealed a significant positive relationship $(r=0.743$ in groundnut). Similar relationship between proline content and pest incidence was revealed by Jinsa et al. (2014) ${ }^{[13]}$, who observed lower proline content in soybean resistant to caterpillar damage. Similar results were also obtained by Roy et al. (1988) who reported higher proline accumulation due to rice brown plant hopper attack in rice.

\section{5) Soluble Proteins}

The crop receiving organics recorded significantly less protein content of $20.66 \mathrm{mg}$ per g $4.56 \mathrm{mg}$ per g in groundnut as against $4.12 \mathrm{mg}$ per $\mathrm{g}$ in groundnut in conventionally grown plants and 3.16 to $3.89 \mathrm{mg}$ per $\mathrm{g}$ in conservation agriculture treatments. The plants receiving organic amendments showed low amounts of proteins thus making the plant unpalatable to insects and rendered them unsuitable for insect nutrition. Further, the correlation studies revealed a significant positive relationship $(\mathrm{r}=0.689)$ between soluble proteins and pest infestation and damage. This is in agreement with the observation of Jinsa et al. (2014) ${ }^{[13]}$ who stated that proteins were important constituents in insect nutrition and 
the strains with higher soluble protein would naturally have high defoliator infestation.

\section{Conclusion}

Biophysical characters in groundnut like leaf succulence and leaf area revealed significant positive relationship with incidence of defoliators but leaf thickness was observed to have significant and negative relationship. Higher phenols, lower free amino acids, lower total sugars and reducing sugars, lower protein content were present in plants nourished with organics, followed by conservation farming and conventional farming system. These metabolites are on the opposite in conventional farming. These accumulated biochemical constituents and their quantities in plant tissues impart resistance $\mathrm{v} / \mathrm{s}$ pests in crops.

\section{References}

1. Abhilash HR. Biophysical basis of resistance and evaluation of border and barrier crops in managing chilli murda. M.Sc. (Agri.) Thesis, Univ. Agric. Sci., Dharwad (India), 2018, 121.

2. Amjad M, Ihsan-ul-Haq, Kakakhel S, Khokhar MA. Morphological and physiological parameters of soybean resistance to insect pests. Asian J Plant. Sci. 2003; 2(2):202-204.

3. Barrs HD, Weatherley PE. A re-examination of the relative turgidity technique for estimating water deficits in leaves. Australian J Biol. Sci. 1962; 15:413-428.

4. Bates LS, Waldeen RP, Teare ID. Rapid determination of free proline for water stress studies. Plant Soil. 1973; 39:205-207.

5. Bray HG, Thorpe WV. Analysis of phenolic compounds of interest in metabolism. Biochem. Anal. 1954; 1:27-52.

6. Chhabra KS, Kooner BS, Sharma AK, Saxena AK. Sources of resistance in chickpea, role of biochemical components on incidence of gram pod borer, Helicoverpa armigera (Hub.). Indian J Entomol. 1990; 52:423-430.

7. David H, Easwaramoorthy S. Physical resistance mechanisms in insect-plant interactions. In: (Eds.) Ananthakrishnan TN, Raman A. Dynamics of Insect Plant Interactions: Recent Advances and Future Trends, Oxford \& IBH Publishing Co., New Delhi, India, 1988, 45-70.

8. Dhaliwal GS, Jindal V, Dhawan AK. Insect pest problems and crop losses: Changing trends. Indian Journal of Ecology. 2010; 37:1-7.

9. Dhir BC, Mohapatra HK, Senapati B. Assessment of crop loss in groundnut due to Spodoptera litura (F.). Indian Journal of Plant Protection. 1992; 20:215-217.

10. Elanchezhyan K, Murali Baskaran RK, Rajavel DS. Biochemical basis of resistance in brinjal genotypes to shoot and fruit borer, Leucinodes orbonalis Guen. J Ent. Res. 2009; 33(2):101-104.

11. Halder J, Srinivasan S, Muralikrishna T. Biochemical basis of resistance to spotted pod borer, Maruca vitrata (Geyer) in Mungbean. J. Ent. Res. 2006; 30(4):313316.

12. Jinsa N, Giraddi RS, Biradar DP. Biochemical basis of induced resistance against major pests of soybean nourished with organics. Biochem. Cell. Arch. 2012; 12(2):295-301.

13. Jinsa N, Giraddi RS, Biradar DP. Biophysical basis of induced resistance as influenced by bio-rational nutrient management on lepidopteran pests of soybean. J Ecofriendly Agric. 2014; 9(1):48-52.
14. Jones FGW. Pests, resistance and fertilizers. Proc. Int. Potash Inst. 1976; 12:233-258.

15. Joshi, Kumar NH. Characterization of groundnut (Arachis hypogaea L.) germplasm in relation to major foliar pests and diseases. Ph. D. Thesis, Saurashtra University, Rajkot, India, 2005.

16. Kulkarni KA. Bio ecology and management of S. litura (F.) (Lepidoptera: Noctuidae) on groundnut (Arachis hypogaea L.). Ph. D. Thesis. University of Agricultural Sciences, Dharwad, Karnataka, India, 1989.

17. Nelson N. A photometric adaptation of the somogyi method for determination of glucose. J Biol. Chem. 1944; 153:375-380.

18. Norris DM, Kogan M. Biochemical and morphological basis of resistance. In: Maxwell FG, Jennigns PR (Eds). Breed. Plants Resist. Insect, John Willey and Sons, New York, 1980, 23-62.

19. Painter RH. Insect resistance in Crop plants. The Macmillan Co., New York, 1951, 520.

20. Patil RK. Eco-friendly approaches for the management of S. litura (F.) in groundnut. Ph. D. Thesis, University of Agricultural Sciences, Dharwad, Karnataka, India, 2000.

21. Peter AJ, Shanower TG, Romeis J. The role of plant trichomes in resistance: a selective review. Phytophaga. 1995; 7:41-63.

22. Ramachandrareddy MA, Narayanreddy YT, Shivareddy N, Anjanappa M. Effect of organic and inorganic sources of NPK on growth and yield of pea (Pisum sativum L.). Legume Res. 1998; 21(1):57-60.

23. Ramgopal, Ghahshyam S, Singh GR, Gopal R, Singh R. Effect of irrigation and nitrogen levels with and without FYM on the yield and water use of French bean. Farm Sci. J. 2003; 12(2):182-183.

24. Rao CN, Panwar VPS. Biochemical plant factors affecting resistance to Chilo partellus (Swinhoe) in maize. Ann. Pl. Prot. Sci. 2002; 10:28-30.

25. Rauzi F. High rates of nitrogen change composition of short grass rangelands in South. Inst. Res. 1978; 32(1):24-30.

26. Savage GP, Keenan JI. The composition and nutritive value of groundnut kernels. (Ed. J. Smartt), the groundnut crop: A scientific basis for improvement, Chapman and hall, London, United Kingdom, 1994, 173-213.

27. Sharma OP, Lavekar RC, Pande AK, Rathod KS, Jafri AA, Murthy KS et al. Validation and adoption of biointensive ASHTA cotton IPM module at Sonkhed and Dongargaon villages in Southern Maharashtra. Ann. Plant Prot. Sci. 2001; 9(2):193-200.

28. Shwetha BN. Studies on nutrient management through organics in soybean-wheat cropping system. M.Sc. Thesis, Univ. Agril., Sci., Dharwad (India), 2007.

29. Singh SP, Jalali SK. Management of Spodoptera litura (Lepidoptera: Noctuide) in India. Proc. National Scientists Forum Spodoptera litura, ICRISAT Asia Centre, ICRISAT, Patancheru, Andhra Pradesh, India, 1996, 2-4, 1997, 27-65.

30. Singh SP, Agarwal RA. Role of biochemical components of resistant and susceptible cotton and okra in ovipositional preference of cotton leaf hopper. Proc. Indian Acad. Sci. 1988; 97:545-550. 